International Journal of Social Science And Human Research

ISSN(print): 2644-0679, ISSN(online): 2644-0695

Volume 04 Issue 12 December 2021

DOI: $10.47191 /$ ijsshr/v4-i12-63, Impact factor-5.586

Page No: 3916-3920

\title{
The Formation of Teenager Virtual Self-Image on Instagram Social Media
}

\author{
Rahmadya Putra Nugraha S \\ Mercu Buana University, Jakarta, Indonesia
}

\begin{abstract}
This research intended to comprehend the virtual self-image formation process by adolescents and the factors that could support self-image formation on Instagram social media. The subjects from this research were late adolescents who used Instagram actively. The research method used was a qualitative method with a phenomenological approach. Then, the primary technique used in this research was a semi-structured interview technique.

The result obtained indicated that the respondents wanted to show content that was considered interesting enough to be seen by others by showing things that the respondents thought became the strengths they had. The respondents were also pleased if they got positive comments on every shared content; it made the respondents respond back to the comments given. The personal branding done by the respondents on Instagram made an increasing existence of each respondent's self and added the confidence to upload content on Instagram.

According to the research results, it can be concluded that the respondents can fulfill aspects of self-image, i.e., appearance, behavior/attitude, mindset and emotional, overall personality, self-confidence, and self-representation, by displaying a positive image in each shared content. As for the factors that influence the self-image-building process consist of experience, exposure, education, environment, and use frequency.
\end{abstract}

KEYWORDS: self-image, virtual, adolescent, Instagram.

\section{INTRODUCTION}

The development of information and communication technology has an impact on the ease internet access. Currently, internet users can access a lot of information regarding entertainment, news, or other information due to the support of the internet (Mansur, et al, 2021). There are various kinds of information to be obtained like written information, photos and videos. The exchange of information that exposes the internet as a communication medium is commonly called Computer Mediated Communication (CMC). CMC is a new communication tool in the era of technological and social changes (Pratiwi, 2014).

The results of a poll study conducted by the members of the Association of Indonesian Internet Service Providers (APJII, found that there were 73.7 percent of internet users in Indonesia in 2019-2020, which increased from 64.8 percent in 2018. When combined with the finding derived from the Statistics Indonesia (BPS) projection, the population of Indonesia in 2019 was $266,911,900$ million, so that Indonesia's internet users were estimated to be 196.7 million users. This number showed an increase by 171 million with a penetration of 73.7 percent or an increase of about 8.9 percent or around 25.5 million users (Irso, 2020).

The increase in internet use that occurs every year has an impact on social communication between individuals, along with the emergence of new spaces such as social media (Indrawan, Efriza, \& Ilmar, 2020). Social media is part of the information infrastructure and tools for disseminating content about media. Media content consists of personal messages, news information, ideas, and cultural products in digital form (Howard \& Parks, 2012).

The virtual world sometimes involves openness of personal identity which can identify and construct oneself in the virtual world. Meanwhile, anonymity in the cyber world can protect the user's identity from unwanted things. Cyber culture is closely related to social networking, identity, privacy, and network formation. Cyber culture also describes the use of social media in terms of interpretation, meaning, context, perception and behavior (Carter, 2020).

The various types of platforms that exist on social media are very attractive to late teens, especially Instagram. Instagram is usually used to find inspiration, share travel experiences, see the latest trends, chat with other users, and to shop online (Prilyantinasari \& Mulyana, 2020). Instagram is one of the most popular social media platforms in the world, especially among young adults. Until the first quarter of 2021, the number of active Instagram users worldwide reached 1.07 billion and 354 million users aged 25 to 34 years. In Indonesia, there were 91.77 million Instagram users until July 2021. The majority of users were in the 18-24 year age group or 36.4\%. Instagram is the third most used social media platform after YouTube and WhatsApp (Rizaty, 2021). 


\section{The Formation Of Teenager Virtual Self-Image On Instagram Social Media}

Instagram acts as a site to build one's self-image in the virtual world. The higher the likes and followers of the users, the higher the self-image to be owned (Zakirah, 2020). Users, especially teenagers often form a self-image that is not in accordance with the existing reality. Self-image is an individual's view or assessment of himself, certain individual can perceive himself either consciously or unconsciously. The self-image that is formed on Instagram is influenced by the environment around teenagers. This can be found in urban communities who have technological sophistication in smartphones used in everyday life (Ismanto, 2018).

Teenager virtual self-image is reflected in the formation of virtual identity. Self-image is an assessment or view of a person about himself and about the body and character he have (Putri, 2018). Such self-image has been formed since childhood. The past has formed the individual's self in the present, which reflects a person's view of himself both physically and psychologically. Selfimage is a source of energy so that people can motivate themselves and others, which make them more enthusiastic in learning, working, and communicating with others.

The self-image formed in Instagram is a self-image that can describe one-self in cyberspace, sometimes this self-image is formed based the evaluations or comments of others. Unwittingly, self-image that is formed is part of the results of information obtained from comments, assessments or evaluations of others against the individual whether something is something good, bad, beautiful, unattractive, thin, full, compassionate, friendly, and so on. Every individual wants to show his or her best side in order to create a good impression as he desires to portray on Instagram (Mulyana, 2001). The popularity of Instagram among teenagers is a real fact regarding the formation of a self-image that is different from the reality. Each individual has their own self-image, be it the actual self-image (real self) or the desired self-image (ideal self). The skills possessed, environmental conditions, attitudes and personal opinions will affect individuals in forming self-image. (Burns,1993).

Based on the above background, this study aims to determine the process of self-image formation through Instagram social media among the teenagers. The rapid development of Instagram has become a site for teenagers to express themselves in the virtual world. The tendency of teenagers to manage their original self-image can lead to a desired virtual self-image. This study is very important to conduct as an overview of the self-image formation on Instagram among teenagers.

\section{LITERATURE REVIEW}

\section{Definition of Self-Image}

Self-image is a general view of self or the image that we design for ourselves. Self-image tends not to be the same as a person's real life, but individuals believe in that self-image. Self-image forms the personality that exists within oneself for how to behave, show appearance, make decisions, and appreciate every advantage and disadvantage (Zakirah, 2020). Self-image is a part of the personality structure which consists of structured and functional autonomy and independence, which is the inner setting of each individual as the main character of the personality. Self-image includes everything that represents a person's ideas, beliefs, abilities, attitudes and behavior related to his personality (Magdalena, 2015). According to Mahardika and Farida (2019), virtual self-image is one of the new forms of reality depicted in content shared on social media.

Some of the definitions above show that self-image is very important for a person, especially if it is formed on a virtual basis. The self-image formed by a person in the virtual world is a self-image that can describe such person and can reflect what kind of person he is. One must be able to distinguish between the original self-image and virtual self-image since an individual will be assessed based on the point of view of other people or followers in the virtual world regarding the formed image. Therefore, a person can form a positive self-image and it will have a good impact on the individual or others.

\section{Teen Self-Image on Instagram}

The self-image displayed in the virtual world is sometimes more desired rather than the real self. Self-presentation in the virtual world changes the meaning from real life to virtual live and this is performed by individuals to form a virtual self-image (Hanika, 2016). Moreover, the self-image formed by teenagers on Instagram tends to show an image that looks different from others, one of which is by uploading the most interesting photos/videos about themselves and showing things that are really different from the real situation (Nurendra \& Purnamasari, 2017).

The assessment of self-image formed by oneself on Instagram encourages teenagers to share a post that is oriented towards self-branding in the media, because self-image is likened to self-identity to be introduced to others, then it must be good in the view of others. Therefore, many teenagers try to present their best self-image in order to make an impression according to the image created, so as to create a positive impression among the others when they see them (Hikmat, 2018).

Instagram has several benefits for users. The use of Instagram certainly brings a lot of convenience for teenagers in representing themselves to others. However, Instagram also has several negative impacts on its users, such as a crisis of confidence, social competition, and difficulty to accept the existing reality (Mahardika \& Farida, 2019).

\section{STUDY METHODS}

This was a qualitative study. Qualitative study refers to activities carried out in a certain location and relates to a naturalistic approach to the world. It tries to study the elements that exist in certain environment in order to create meaning or capture the meaning of the phenomenon based on the existing point of view in society. (Denzin \& Lincoln, 2005). This article applied phenomenological study 


\section{The Formation Of Teenager Virtual Self-Image On Instagram Social Media}

which is described as general meanings of events experienced by individuals, about certain concepts or phenomena, by exploring the structure of human consciousness (Creswell, 2017). Furthermore, Creswell (2017) also explains that there are several characteristics in phenomenological study such as, emphasis on the phenomenon to be explored based on a concept, exploration of phenomena in a certain group that has experienced the phenomenon, and a study conducted by researcher to isolate himself from the study by relating personal experience to the phenomenon under study. So, the researcher aims to find out more about the description of the process of teenager self-image formation on Instagram based on aspects of self-image and the factors of selfimage formation on Instagram.

The recent study applied the non-probability sampling technique. In the non-probability sampling technique, the researcher used purposive sampling and convenience sampling as sampling methods. Purposive sampling tries to increase the scope of the data sought in order to obtain reliability, so that all findings will be based on the process of local conditions and values wherein all affect each other (Alwasilah, 2015).

The purposive sampling technique was chosen since not all samples had criteria that matched the phenomenon under study. Researchers chose this technique because it set certain criteria that must be met by the samples involved in the study. The inclusion criteria for the study samples were:

1. Late teenager (18-24 years)

2. Domiciled in Yogyakarta

3. Instagram active users (opened Instagram at least 3-5 times a day)

Data collection in this study applied the interview method and the results became the main information in the study. The interview method is a conversation carried out through a question and answer that is directed to achieve a certain goal (Poerwandari, 2017).

\section{RESULTS}

\section{Appearance}

Instagram was used quite well by the respondents to form self-image. The respondents provided information related to self-image that the respondents wanted to show visually and had a positive impression to be seen by others. These findings are in accordance with a study conducted by Sternberg \& Sternberg, (2012), which found that visual appearance was very important because the human brain worked based on the visual code, then the auditory code, and finally the semantic code. Therefore, to get the impression as desired, an individual must consider or be careful in posting an upload via social media, so that other users can give a positive impression of the individual (Richey, et al, 2016).

The content displayed by respondents on Instagram regarding what they found interesting was shown on Instagram. Through this content, respondents could express their creativity and provide information related to the places visited. In the content shared by respondents, they physically displayed themselves or other people so that the content displayed could be more attractive. Respondents shared things that they considered fun and productive. When individuals present themselves on Instagram, they can give an impression to others by showing what they want to be displayed according to their desires. Usually, individuals want to display an attractive self-image and be accepted by others with a certain purpose. In certain cases, the effort acts as impression management, that is, a technique used by a role player to create certain impressions in certain situations in order to obtain certain goals.

\section{Behavior and Attitude}

The quite instrumental thing in self-image formation of the respondents was the strengths each respondent which were shown visually and shared on Instagram stories or uploaded to Instagram feeds. The respondents tended to be more willing to share only their strengths rather than weaknesses. According to the respondents, it was enough to show positive things on Instagram, and they preferred to ignore negative things that should not be displayed on Instagram. According to Hill \& Denman (2016), showing activities on social media is one form of presenting oneself to others. The emergence of social media such as Instagram can affect the way a person views himself and what he wants to be shown to others. This is in accordance with the results of previous study that everyone had a certain attitude to accept positive things and reject negative things of a stimulus or an existing object, an attitude that is taken is as a form of self-evaluation (Syamaun, 2019). Furthermore, the attitude of accepting each weaknesses and strengths or self-acceptance of oneself to be able to have a positive view of who the individual really is does not appear directly but must be developed by the individual.

\section{Thinking Pattern and Emotion}

According to Xie and Wijarnako (2017), self-image is an assessment of oneself. It is important for oneself since they way the individual assesses himself greatly determines many things in him. Other people's assessment of the individual is not as important as the individual assessment on himself. The individual's self-life depends on the self-image he forms. In the three respondents, certain feelings emerged when uploading content on Instagram feeds or instastory or snapgram, starting from happiness because they could produce content to be viewed by many people and also the anxiety that arose from within the respondents when they 


\section{The Formation Of Teenager Virtual Self-Image On Instagram Social Media}

wantedto share photos or videos to be uploaded on Instagram feeds or instastory. The respondents were afraid of negative views or comments from followers on Instagram when they shared certain moments, although the content shared by the respondents tended to be positive. Such afraid feeling could not be separated from the emotions generated. Emotions are specific feelings to be shown to other people's reactions to someone or an event that is experienced and reflect the feelings of pleasure, anger, sadness, or fear. Emotional maturity is also influenced by age, so that the emotional maturity possessed by teenagers can be influenced by factors that exist within them.

\section{Experience}

The new experiences gained by the respondents could form a distinct impression to be felt by the respondents. The three respondents stated that those experiences had an impact on the real lives of the respondents. The contents presented were more positive because it encouraged the respondents to be more productive in content creation. The new information obtained on Instagram was also an experience that the respondents obtained from observations on Instagram. The respondents had their own social environment where there were responses from that environment, such as the respondents' friendship environment, and the three respondents also interacted with each other.

\section{Exposure}

The respondents got new things from Instagram. These new things encouraged the three respondents to be able to adapt to the developments on Instagram based on the input or recommendations from followers as a form of evaluation of the content shared by the respondents on Instagram. The respondents were not open enough on Instagram because they only described themselves in general on Instagram. The information shared did not fully describe their characteristics. They only shared certain things considered appropriate to be displayed such as positive or fun things.

\section{Education}

The learning obtained by respondents on Instagram was regarding getting new information on Instagram, such as information regarding the individual's ability to understand something on Instagram, getting more concise news, as well as being able to explore the information in more detail. The respondents could adjust to the information that appeared on Instagram. In such adjustment, the three respondents could understand more and hoped to adapt to the development of Instagram in the future. In addition, the three respondents also obtained all kinds of information or the latest trends from Instagram, such as tourist attractions, restaurants or food stalls, or fashion style.

\section{Environment}

The lifestyle displayed by the three respondents on Instagram received responses aimed at the lifestyle or style of the three respondents. The respondents continued to be themselves even though they saw the trend styles on Instagram. Instagram was also quite influential in the daily lives of respondents and they could express themselves better in the content displayed on Instagram. The respondents were quite interested in the trending styles on Instagram, sometimes the three respondents follow the trend outfit style even though it is not one hundred percent, the use of Instagram can actually affect the three respondents

\section{CONCLUSIONS}

The use of Instagram by late teens was proven to have an effect on the self-image formed by teenagers showed visually on Instagram which can be observed from the contents shared on Instagram. The appearance shown was in the form of an attractive positive impression according to the respondents that could be viewed by others or followers on Instagram. Furthermore, regarding the behavioral/attitude aspect, the respondents stated that they could accept the weaknesses and strengths they had, but only showed their strengths on Instagram without showing their weaknesses. Respondents were able to assess themselves on Instagram, which can be observed from the content displayed on Instagram. The way respondents thought about and displayed emotions to others was more positive through positive respond to comments. The three respondents had their own characteristics to be displayed on Instagram which were included in the overall personality aspect. This can be observed through the uploaded content and the study finding which found that Instagram was very influential on the lives of the three respondents.

The factors that could affect the process of teenager self-image formation on Instagram were experiences obtained or shared by the three respondents on Instagram, Based on the exposure or openness aspect shown by respondents in their contents, it turned out that in general, the three respondents were only open when using Instagram. Furthermore, the education obtained by the three respondents was related to a learning process towards the information obtained on Instagram which made the three respondents knew and applied the information. The last factor was the environmental factor commonly called the lifestyle of the teenagers. The respondents showed certain lifestyle which was more or less the same as the real lifestyle. In addition to supporting factors, the researchers also found aspects and factors of new findings that had an effect on the process of teenager self-image formation, namely self-confidence, self-representation, as well as frequency of use. 


\section{REFERENCE}

1) Alwasilah, A. C. (2015). Pokoknya Studi Kasus: Pendekatan KualitatifNo Title (1st ed.). Bandung: PT. K. https://doi.org/Kiblat Buku Utama

2) Carter, D. M. (2020). Cyberspace and Cyberculture. International Encyclopedia of Human Geography (Second Edition), 3, 468-472.

3) Creswell, J. W. (2017). Research design: Qualitative, quantitative, and mixed methods approaches (5th ed.). London: Sage Publisher.

4) Denzin, N., \& Lincoln, Y. (2005). Introduction: The discipline and practice of qualitative research In N. K. Denzin \& Y. S. Lincoln (Eds.), The Sage handbook of qualitative research. The Sage.

5) Hanika, I. M. (2016). Self Presentation dalam Kehidupan Virtual. Jurnal ILMU KOMUNIKASI, 13(1). https://doi.org/10.24002/jik.v13i1.601

6) Hikmat, M. M. (2018). Jurnalistik Literary Journalism. Journal of Chemical Information and Modeling (Vol. 53).

7) Hill, A., \& Denman, L. (2016). Adolescent Self Esteem and Instagram: An Examination of Posting Behavior. Concordia Journal of Communication Research, 3. https://doi.org/10.54416/ntge5234

8) Howard, P. N., \& Parks, M. R. (2012). Social Media and Political Change: Capacity, Constraint, and Consequence. Journal of Communication. https://doi.org/10.1111/j.1460-2466.2012.01626.x

9) Indrawan, J., Efriza, \& Ilmar, A. (2020). KEHADIRAN MEDIA BARU (NEW MEDIA) DALAM PROSES KOMUNIKASI POLITIK. MEDIUM, 8(1). https://doi.org/10.25299/medium.2020.vol8(1).4820

10) Irso. (2020). Survei Penetrasi Pengguna Internet di Indonesia Bagian Penting dari Transformasi Digital. Retrieved from https://www.kominfo.go.id/content/detail/30653/dirjen-ppi-survei-penetrasi-pengguna-internet-di-indonesia-bagianpenting-dari-transformasi-digital/0/berita_satker

11) Ismanto, I. (2018). BUDAYA SELFIE MASYARAKAT URBAN Kajian Estetika Fotografi, Cyber Culture, dan Semiotika Visual. REKAM: Jurnal Fotografi, Televisi, Dan Animasi, 14(1).

https://doi.org/10.24821/rekam.v14i1.2138

12) Magdalena, S. M. (2015). Study on the Structuring of Self-image in Early Childhood. Procedia - Social and Behavioral Sciences, 187. https://doi.org/10.1016/j.sbspro.2015.03.115

13) Mahardika, R. D., \& Farida, F. (2019). Pengungkapan Diri pada Instagram Instastory. Jurnal Studi Komunikasi (Indonesian Journal of Communications Studies), 3(1).

https://doi.org/10.25139/jsk.v3i1.774

14) Mansur, S., Saragih, N., Ritonga, R., \& Damayanti, N. (2021). Fake News on Social Media and Adolescent's Cognition. Jurnal ASPIKOM, 6(1). https://doi.org/10.24329/aspikom.v6i1.827

15) Mulyana, D. (2001). Metodologi Penelitian Kualitatif: Paradigma Baru Ilmu Komunikasi dan Ilmu Sosial Lainnya. Bandung: PT remaja Rosdakarya.

16) Nurendra, A. M., \& Purnamasari, W. (2017). Hubungan antara Kualitas Kehidupan Kerja dan Keterikatan Kerja pada Pekerja Wanita. Indigenous: Jurnal Ilmiah Psikologi, 2(2).

https://doi.org/10.23917/indigenous.v2i2.5649

17) Poerwandari, E. K. (2017). Pendekatan Kualitatif Untuk Penelitian Perilaku Manusia. (Depok, Ed.) (2017th ed.). LPSP3 Fakultas Psikologi Universitas Indonesia.

18) Pratiwi, D. F. (2014). COMPUTER MEDIATED COMMUNICATION (CMC) DALAM PERSPEKTIF KOMUNIKASI LINTAS BUDAYA (Tinjauan Pada Soompi Discussion Forum Empress Ki TaNyang Shipper). Jurnal Komunikasi Profetik, 7(1), 29-44.

19) Prilyantinasari, P., \& Mulyana, A. (2020). The Effect of Instagram Exposure of Hedonic Lifestyle on Dissonance Rates for Digital Native. International Journal of Environment, Agriculture and Biotechnology, 5(2). https://doi.org/10.22161/ijels.52.10

20) Putri, D. M. (2018). proses pembentukan citra diri melalui sosial media instagram mahasiswa universitas bakrie. Universitas Bakrie.

21) Richey, M., Ravishankar, M. N., \& Coupland, C. (2016). Exploring situationally inappropriate social media posts: An impression management perspective. Information Technology and People, 29(3)

. https://doi.org/10.1108/ITP-03-2015-0045

22) Rizaty, M. A. (2021). Inilah Negara Pengguna Instagram Terbanyak, Indonesia Urutan Berapa?

23) Sternberg, R. J., \& Sternberg, K. (2012). Cognitive Psychology (6th ed.). Boston: Wadsworth.

24) Zakirah, D. M. A. (2020). Media Sosial Sebagai Sarana Membentuk Identitas Diri Mahasiswa Universitas Airlangga Surabaya. Jurnal Kopis: Kajian Penelitian Dan Pemikiran Komunikasi Penyiaran Islam, 2(2).

https://doi.org/10.33367/kpi.v2i2.1116 